University of Wollongong

Research Online

Faculty of Law, Humanities and the Arts Papers (Archive)

Faculty of Arts, Social Sciences \& Humanities

$1-1-2014$

The dynamics of transitional justice: international models and local realities in East Timor

Charles Hawksley

University of Wollongong, charlesh@uow.edu.au

Follow this and additional works at: https://ro.uow.edu.au/lhapapers

Part of the Arts and Humanities Commons, and the Law Commons

Research Online is the open access institutional repository for the University of Wollongong. For further information contact the UOW Library: research-pubs@uow.edu.au 


\title{
The dynamics of transitional justice: international models and local realities in East Timor
}

\begin{abstract}
[extract] As Ruti Teitel has outlined, transitional justice can be seen as evolving in three phases. The first involved criminal trials, such as Nuremberg and Tokyo, which sought to hold individuals accountable for abuses of human rights during World War II, and this was buttressed by the development of various international legal instruments to protect rights which today constitute a central aspect of approaches to transitional justice. In the 1980s and 1990s a second phase of transitional justice occurred with postdictatorship tribunals and bodies such as truth commissions, both of which 'thickened' transitional justice by introducing a restorative element. The third phase has involved the normalisation of transitional justice mechanisms through international tribunals and the International Criminal Court, and national and hybrid tribunals and courts increasingly link transitional justice with modern state-building in post-conflict societies. As Lia Kent outlines in this important study, in the case of East Timor (Timor Leste) the 'toolkit' for dealing with post-conflict situations involved both retributive and restorative mechanisms, but international and local agendas can differ widely when it comes to the idea of a society 'moving on'.
\end{abstract}

\section{Keywords}

transitional, east, realities, local, dynamics, models, timor, international, justice

\section{Disciplines}

Arts and Humanities | Law

\section{Publication Details}

Hawksley, C. (2014). The dynamics of transitional justice: international models and local realities in East Timor. Griffith Law Review, 23 (1), 147-149. 
This article was downloaded by: [University of Wollongong]

On: 10 May 2015, At: 23:07

Publisher: Routledge

Informa Ltd Registered in England and Wales Registered Number: 1072954 Registered

office: Mortimer House, 37-41 Mortimer Street, London W1T 3J H, UK

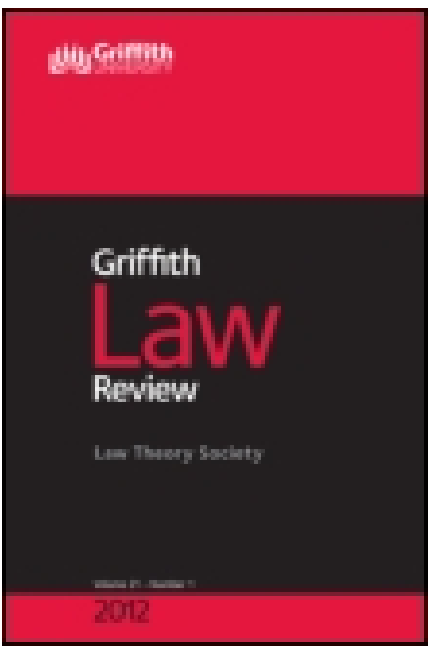

\title{
Griffith Law Review
}

Publication details, including instructions for authors and

subscription information:

http:// www.tandfonline.com/loi/ rlaw20

\section{The dynamics of transitional justice: international models and local realities in East Timor}

\author{
Charles Hawksley ${ }^{a}$ \\ a University of Wollongong \\ Published online: 01 Dec 2014.
}

\section{CrossMark}

Click for updates

To cite this article: Charles Hawksley (2014) The dynamics of transitional justice: international models and local realities in East Timor, Griffith Law Review, 23:1, 147-149, DOI: 10.1080/10383441.2014.944013

To link to this article: http:// dx.doi.org/ 10.1080/ 10383441.2014.944013

\section{PLEASE SCROLL DOWN FOR ARTICLE}

Taylor \& Francis makes every effort to ensure the accuracy of all the information (the "Content") contained in the publications on our platform. However, Taylor \& Francis, our agents, and our licensors make no representations or warranties whatsoever as to the accuracy, completeness, or suitability for any purpose of the Content. Any opinions and views expressed in this publication are the opinions and views of the authors, and are not the views of or endorsed by Taylor \& Francis. The accuracy of the Content should not be relied upon and should be independently verified with primary sources of information. Taylor and Francis shall not be liable for any losses, actions, claims, proceedings, demands, costs, expenses, damages, and other liabilities whatsoever or howsoever caused arising directly or indirectly in connection with, in relation to or arising out of the use of the Content.

This article may be used for research, teaching, and private study purposes. Any substantial or systematic reproduction, redistribution, reselling, loan, sub-licensing, systematic supply, or distribution in any form to anyone is expressly forbidden. Terms \& 
Conditions of access and use can be found at http://www.tandfonline.com/page/termsand-conditions 
Given Steiner's emphasis on the need for ethical consistency, I was surprised to see that while his own 'non-anthropocentric cosmopolitanism' insists on the ethical inclusion of all sentient beings, he is prepared to countenance the exclusion of nonsentient beings ( $p$ 177). This begs questioning on two fronts - whether his position is less non-anthropocentric than he suggests, and if there is not a place for the ethical consideration of non-sentient beings in a holistic cosmopolitanism then where is there?

Structurally, the first half of the book engages with postmodernism and ethics in general - traced genealogically from Nietzsche through Heidegger to Derrida. The second half further discusses the themes of the first, but with a broader focus, and together these may be the reasons that here the argument sometimes becomes repetitive and less organised.

The text demonstrates the breadth and depth of Steiner's philosophical knowledge. This I enjoyed, and I became more engaged with the book than the shadow cast by the early polemics led me to expect I would be. That said, the shadow remains throughout the book. But I am glad enough for my time spent and not only because I am always open to a take-away message that says 'eating meat is never a trivial matter' (p 223).

\section{References}

Carolyn De Cruz (2008) Identity Politics in Deconstruction: Calculating With the Incalculable, Ashgate Publishing Limited.

Jacques Derrida (2002) 'The Animal That Therefore I Am (More to Follow)', David Wills (trans), 28(2) Critical Inquiry 369.

Niall Lucy and Steve Mickler (2009) 'The Postmodern Left' 15(1) Cultural Studies Review 188

Julia Cook

Southern Cross University

julia.cook@scu.edu.au

(C) 2014, Julia Cook

http://dx.doi.org/10.1080/10383441.2014.944012

The dynamics of transitional justice: international models and local realities in East Timor, by Lia Kent, Abingdon, UK and New York, Routledge, 2012, 235 + xiv pp., US\$48.95 (paperback), ISBN 978041553178

As Ruti Teitel has outlined, transitional justice can be seen as evolving in three phases. ${ }^{1}$ The first involved criminal trials, such as Nuremberg and Tokyo, which sought to hold individuals accountable for abuses of human rights during World War II, and this was buttressed by the development of various international legal instruments to protect rights which today constitute a central aspect of approaches

${ }^{1}$ Ruti G. Teitel, 'Transitional Justice Genealogy', Harvard Human Rights Journal, 16, 2003, pp. 69-94. 
to transitional justice. In the 1980s and 1990s a second phase of transitional justice occurred with post-dictatorship tribunals and bodies such as truth commissions, both of which 'thickened' transitional justice by introducing a restorative element. The third phase has involved the normalisation of transitional justice mechanisms through international tribunals and the International Criminal Court, and national and hybrid tribunals and courts increasingly link transitional justice with modern state-building in post-conflict societies. As Lia Kent outlines in this important study, in the case of East Timor (Timor Leste) the 'toolkit' for dealing with post-conflict situations involved both retributive and restorative mechanisms, but international and local agendas can differ widely when it comes to the idea of a society 'moving on'.

After a 24 year occupation of East Timor, Indonesia permitted its twenty-seventh province a vote on autonomy on 30 August 1999. Indonesian-funded and armed militia groups wanted East Timor to stay within Indonesia with greater autonomy, and they threatened and intimidated those who advocated for independence. While the occupation had always been brutal, the decisive vote rejecting autonomy triggered a maelstrom of violence - there were over 1000 murders, human rights abuses, widespread sexual assault, some 400,000 displaced, including a refugee exodus of 200,000 people to West Timor, arson and destruction of infrastructure. The capital of Dili was razed as the Indonesian military, which was meant to be guaranteeing security, pulled out. The Australian-led international force for East Timor (INTERFET) deployed on 20 September, and then, between October 1999 and May 2002, the United Nations Transitional Administration in East Timor (UNTAET) managed the emerging nation's affairs and foreign policy until elections could be held.

For a time, the United Nations ran East Timor and exercised sovereignty on behalf of its people. UNTAET had all the powers of a state, and one of the many matters with which it dealt was the administration of justice. Of particular note was how to proceed on the large number of serious crimes committed during 1999, an issue seen as key, both by the United Nations and by Timorese, to allow the society to 'move on' from the occupation and destruction to build a prosperous future. To assist in this aim UNTAET created two processes, one retributive, one restorative.

UNTAET's Serious Crimes Investigations Unit created the special panels for serious crimes, and these examined instances of murder, sexual offences and torture committed during 1999. The unit could also examine crimes of genocide, war crimes and crimes against humanity committed during any time period. The serious crimes process was attached to the Dili District Court and operated until May 2005. Hybrid panels had international and local judges, and in practice, while these had the capacity to investigate human rights abuses from back to 1975, the concentration was on 1999 and on those who even the East Timorese saw as the 'little people' - the lower ranking militia members who committed the murders and rapes.

As Lia Kent explains, many of the militia leaders responsible for the violence were among the refugees in West Timor, and were not willing to return. Getting those who were seen as 'most responsible' to face justice was a highly political exercise. The move to have Indonesian armed forces chief (and by then presidential contender), General Wiranto, face charges over his role in events was completely unsuccessful. While there were some convictions, a perception that the main culprits had gone unpunished meant that people felt let down. Many East Timorese became increasingly disillusioned with the legal path. The Timorese political elite also quickly moved to a position that encouraged accommodation with its former occupier. 
The other part of the UNTAET approach was the Commissão de Acolhimento, Verdade e Reconciliação (CAVR; Commission for Reception, Truth and Reconciliation), which was dissolved in December 2005. This body had a much wider mandate than the special panels, and was created to seek the truth of the occupation, deal with less serious crimes through community reconciliation, produce a report and publish recommendations. As a restorative justice approach, CAVR offered more scope for creating an official chronicle of the sufferings of the people of East Timor, but, as Kent deftly explains, the creation of a national history of struggle involved the collection of testimonies in hearings all over East Timor, and not all were happy about the results as recording their stories seemingly did little to alter their material conditions.

The CAVR final report, Chega! (Enough!) now forms part of a national story that includes both resistance fighters and the 'small people' of East Timor, and has been widely accepted; but the novelty of Kent's work lies in the discussion of how neither the trials nor the CAVR actually satisfied the diversity of demands for justice. Kent demonstrates how people began to create their own "locally grounded form of "justice" ( $p$ 178), working both with and outside official mechanisms to construct memorials, create victims' support groups, and pursue political recognition of their losses and hardships. Kent explains how the official processes of transitional justice have been joined by 'unofficial memory practices' ( $p$ 174), many of which draw on Timorese tradition and the central role of ancestors in ordering society to restructure their shattered worlds. This analysis of why East Timorese expectations of justice differed from the reality that came to pass forms the central part of Lia Kent's study. The book also provides a rich summary of transitional justice approaches in other parts of the world and is a valuable addition to a growing literature in post-conflict state-building.

\author{
Charles Hawksley \\ University of Wollongong \\ charlesh@uow.edu.au \\ (C) 2014, Charles Hawksley \\ http://dx.doi.org/10.1080/10383441.2014.944013
}

Regulation of sexual conduct in UN peacekeeping operations, by Olivera Simic, Heidelberg, Springer, 2012, 194 + xxii pp., US\$132.05 (paperback), ISBN 978364 2427855

In the context of the increasing number of peacekeeping operations (PKOs) since the end of the Cold War, and the corresponding rise in the number of accounts of sexual exploitation of local women by peacekeepers during PKOs, Olivera Simic systematically unpacks the United Nations Secretary-General's Bulletin on Special Measures for Protection from Sexual Exploitation and Sexual Abuse (SGB) promulgated in 2003. Simic begins her analysis by providing a backdrop to the 